\title{
Research on Innovation and Practice Ability of Computer Major Students in Contemporary Universities
}

\author{
Jun $\mathrm{Xi}^{1, a}$ Wei He${ }^{2, b}$ \\ ${ }^{1}$ Xinyu University, Xin Yu, Jiang Xi, 338004, China
}

Keywords: University, Computer Science, Innovation Ability, Practical Ability

\begin{abstract}
In order to improve the university computer professional students' innovation and practical ability, and puts forward the method of using new technology lectures, project development team, extracurricular skill training is built in accordance with the actual situation of the multi-level practice platform. These methods are of great significance to improve students' ability and practical ability, and achieve the goal of personnel training in Colleges and universities.
\end{abstract}

\section{Introduction}

Computer science knowledge update quickly, new technologies, new techniques, new devices, new software is constantly emerging, such as the local colleges restricted by educational condition, lagging teaching content, teaching mode of the single, rigid teaching method, experiment equipment is old, the phenomenon such as "heavy theory, light practice". This not only restricts students' innovative consciousness and innovative ability, but also is bad for the cultivation of talents. Therefore, as local colleges and universities in improving the practice teaching level and training students' practical ability and innovation ability, it is necessary to explore the suitable road for themselves according to their own reality.

\section{To Improve the Innovation Ability and Practical Ability of Computer Science Students}

The new technology lecture will be used to enrich students' life, broaden their horizons and expand their knowledge. To this end, our hospital held a series of special lectures, shall be borne by the various teaching and research section, but also invited companies such as huawei, aptech top management for the students to do project development and management of the seminar. Let students keep abreast of industry trends and track the latest research in the IT field. At the same time, through these lectures, teachers have deepened their communication with students, expanded their influence, and created favorable conditions for follow-up project groups and research group activities.

Project development team, in recent years, university undergraduate course graduation design has many problems, such as the old thesis topic selection, the choice surface is narrow, such as student management system, library management system, the information such as laboratory equipment management system management system such as the title of a share, and every year in repeated use. Some employers and enterprises reflect the lack of practical ability and experience in programming and development of computer science graduates. The main reason is that students lack of engineering practice experience, such as in software design and production, students are still stay in realize the algorithm of character under the interface problems with the language, unable to develop a graphical interface application system. There are fewer students who can do the research on the hardware, and there are only the design principles on the structural level, which can't be connected with the actual situation. Therefore, the training and guidance of engineering practice is indispensable to improve the practice ability of undergraduates. The development group aims to strengthen students' professional knowledge, cultivate students' engineering quality and teamwork spirit, and alleviate the contradiction between theoretical knowledge and engineering practice. The members mainly focus on the senior students, to guide the teacher's actual project or virtual project as the project, and to study independently under the guidance and training of teachers. Encourage and introduce students to the program. It is shown that the setting of the project team has greatly 
changed the students' theoretical foundation and weak ability.

Develop extracurricular computer hobby training class to improve students' hands-on ability. Organizations in various parts of the computer information class analysed austere modality students in an after-school skills training, make full use of their spare time, teaching department set theory teaching is complementary, focus on practical training way, learn to let the students learn a lot, and very close to the knowledge of the computer information industry. Theoretical teaching mainly teaches electronic component knowledge and computer basic knowledge. Here, students can really into the computer world, meet all kinds of electronic components and learn how to use computer aided drawing, knowledge in some unit of choose and employ persons, have provided special jobs, relevant industry needs. The theoretical knowledge taught in class will not involve so much practical knowledge. The extracurricular skills training class, to do this, is to bring students into the computer world, to enable students to learn industrial skills.

\section{Adopt Scientific Teaching Mode to Cultivate Students' Innovation Ability}

In the process of teaching, the teacher should guide students step by step to master the methods to solve the problem, let the student directly involved in the teaching, give full play to students' subjective initiative, develop the innovative ability of students, make students in learning a sense of accomplishment, it helps cultivate their set scientific attitude and mastering scientific method. "The most effective way to learn is to let students learn in the process of experience and creation." Use computer multimedia, big screen projection, network and other advanced education methods instead of traditional chalk and blackboard. In class, I focus on the problem of creating, provide atmosphere, let the students find problems in the practice, and set out to solve the problem, so as to become the master of learning, teachers become students "collaborators". For example, in explaining word design, let students familiarize themselves with the word interface, learn the functions of each menu item, and help students learn to use the help menu. When students start to learn the software, they feel a lot of difficulties, and every few steps will encounter new problems and even conflict. At this time, as a teacher will patiently to guide and encourage students to discover new problems, and guide students to boldly experiment, and provides the feasible processing method, so that the students in the operation summed up the regularity of the method to solve the problem.

\section{To Improve the Quality of Practice Classroom, We Must Use Computer Information Technology.}

Any mature, advanced technology and successful practice, we need correct theoretical guidance. Theory is usually in the room, interior theory is an important part of practice teaching. Classroom teaching at present, many schools have installed equipment, theoretical teaching, multimedia projector, computers, tape recorders and other modern information technology and the multimedia teaching, in order to display text in the form of a student, sound, like a rich variety of teaching content, broke the single teaching mode and teaching atmosphere is very boring, optimize the classroom teaching, improve the classroom teaching ability, improve the teaching effect and teaching quality. Using computer class course "computer culture basis", the development of the first computer, stimulate students' interest in learning, and use the training in the process of teaching, make students quickly grasp the behavioral essentials, observation, analysis and practical operation of students.

\section{Using Computer Information Technology to Automate Office Work Effectively Improve Work Efficiency}

Student learning is often isolated as a result of the knowledge is difficult to form good learning effect, also often can only make a particular part of the understanding and application of knowledge or skill, it is difficult to form a comprehensive information technology development and innovation ability. Engineering colleges and universities, training application talents for the purpose of 
adapting to the needs of social development, formulate corresponding innovation professional education reform, and influence the daily work of teachers.

On the basis of computer network information technology, give full play to the effectiveness of the network course, give full play to the practical function of network course, master to adapt to the life and health life, basic knowledge, basic skills and methods, in order to highlight student's main body status, promote the students' autonomous learning level and ability, cooperative learning and inquiry learning, encourage students to teachers is the combination of each other. Enrich the teaching content, classroom teaching and learning mode, time and space is very limited and using computer information technology to create better work, for the teacher and the student to obtain the basic knowledge, skills, and healthy way, practice to provide a good communication platform, modern science and technology has become a practical teaching link. By strengthening institutions or expert guidance teacher, outstanding student's main body status, increase the proportion of practice teaching, and establish a model of the university of computer application talents of engineering practice ability will push based computer science teaching methods, to further deepen the teacher through the Internet or online communication between teachers and students, E-mail and other forms, organize, guide and help students to learn and exercise.

\section{In Order to Improve Students' Ability of Employment and Innovation, We Should Optimize Practical Teaching}

College of education objectives, requirements to improve students' ability to apply the knowledge for solving the problems, and strengthen the practice teaching, fully embody the highlight the characteristics of higher vocational colleges, so as to play to the advantages of higher vocational colleges. To this end, we should strengthen the design of practical training and practice, as well as the construction of laboratory and training platform. It is necessary for students to participate in practice and research activities based on the teaching of wide - caliber subject and to carry out overall design and practical implementation of the teaching content system of practice. Practical teaching should constitute a large proportion of college teaching plan, and practical teaching should be designed and organized according to basic skills, professional skills and skills that students must master. It should also be noted that, with the development of economic society and technology, the training mode and calibre should not be the same as the requirement of the knowledge structure and capability level of higher vocational students. From cultivation program, teaching organization and management to the professional construction and reform of classroom teaching, examination, should be adjusted according to the needs of society in the quality of higher vocational colleges and improve, to achieve teaching with production and with the combination of student employment.

\section{Conclusion}

In view of the characteristics of colleges and universities, this paper puts forward the methods and measures of how to build practice platform, integrated application of these methods, certain achievements have been made in the teaching practice, the students' innovation ability and practice ability has the obvious enhancement, the spirit of the students' autonomous learning and ability are improved greatly. At the same time, it has also transformed some teachers' thinking of "retheory and light practice", so that they can combine their scientific research direction and how to improve students' practical ability. The practice platform is a system engineering, and many other links, such as open lab, course design, experiment project, etc. As long as we put these aspects of the work, to guarantee the necessary funds, set up the idea of take the student as the main body, can make the practice teaching on a new step, and implement personnel training target, strengthen the competitiveness of the talents in the society.

Computer science is a practical subject, especially school education training target is applied higher specialized talents, therefore, to construct university computer teaching is different from ordinary computer teaching mode of higher education, on training students' innovative ability and the ability to apply professional design practice teaching. In computer teaching is not enough to 
only focus on theory teaching, must strengthen practice, closely combined with production practice, how to make students strengthen the consciousness of the computer and master computer basic operation, improve the level of computer application gradually.

\section{References}

[1] xu xiaolin, li shiyong. Exploration of practical teaching of software engineering innovative talent cultivation -- taking hunan university as an example [J]. University education science, 2007, (2) : 66-68.

[2] fan liangnan. The exploration of innovation ability and practical ability of graduation design of information discipline [J]. Computer education, 2008, (6) : 12-14.

[3] Lou yu. On the cultivation of students' innovation by computer teaching [J]. Journal of education college, guangxi, 2015, (5).

[4] research on the cultivation of practical innovation ability of college students in computer science [J]. Jia pentao, luo xiaoxia, shi xiaonan. Education teaching BBS. 2017(07)

[5] the application of integrated practice teaching in software engineering majors [J]. Luo xiaoxia. Introduction to science and education (top 10). 2015(12)

[6] research on innovation ability of computer professional students -- taking xi 'an university of science and technology as an example [J]. Shi xiaonan, jia pescadao, luo xiaoxia. Software guide (education technology). 2015(11)

[7] exploration and practice of innovation ability cultivation of software engineering students [J]. Shi xiaonan. Technology innovation guide. 2014 (29).

[8] to train students' innovative abilities in science and technology competitions [J]. Chen xin. Invention and innovation (integrated technology). 2011(02)

\section{邮寄地址 : 江西省南昌市昌北开发区南昌理工学院英雄校区白老师收 13479126199 邮编 330044}

